Vol. 2 No. 1- April 2021

\title{
The Impact of Tariff Reduction on Poverty in Indonesia: Regional Level Analysis
}

\author{
Rizka Aulia ${ }^{1 *}$, Kangkook Lee ${ }^{2}$ \\ Statistics of Sumatera Barat Province, Padang, Indonesia ${ }^{1}$ \\ Graduate School of Economics, Ritsumeikan University, Shiga, Japan ${ }^{2}$ \\ Email: ${ }^{1}$ rizka@bps.go.id, ${ }^{2}$ kangkooklee@gmail.com.
}

*) Corresponding author

\begin{abstract}
The study examines the effect of trade liberalization on poverty reduction across districts in Indonesia during the period from 2000 to 2016 using the fixed effect approach. Tariff exposure is used to measure trade liberalization, which is computed at the district level by combining information on sector composition of the economy in each district and tariff lines by sectors. This study also distinguishes between tariff exposure for output products and intermediate inputs. This produces a measure indicating how changes in exposure to tariff reductions in outputs and inputs vary by region over the period. Due to the available multi-district and 17-year dataset, the study includes a set of fixed effects: the district-fixed effects and the time-fixed effects, which controls for aggregate time trend. The results indicate that the impact of output and input tariff on regional poverty headcount index $(\mathrm{PO})$ is different. Output tariff has a negative correlation with poverty, while input tariff has a positive correlation with poverty. This suggests that trade liberalization in input sectors could reduce poverty in Indonesia. It is also found that GRDP per capita, literacy rates, and road length are negatively associated with poverty. Also, the effect of reducing input tariffs on poverty reduction will be larger if the districts have higher GRDP per capita and higher literacy rates.
\end{abstract}

Keywords: poverty, tariff reduction, regional tariff exposure, output tariff, input tariff.

ARTICLE INFO
Received: March 02, 2021
Received in revised form: April 16, 2021
Accepted: April 25, 2021

doi: 10.46456/jisdep.v2i1.111 (C) 2021 The Author
JISDeP - The Journal of Indonesia Sustainable Development Planning Published by Centre for Planners' Development, Education, and Training (Pusbindiklatren),

Ministry of National Development Planning/ National Development Planning Agency (Bappenas), Republic of Indonesia
Address: Jalan Proklamasi 70,

Central Jakarta, Indonesia 10320

Phone: +62 $2131928280 / 31928285$

Fax: +62 2131928281

E-mail:

journal.pusbindiklatren@bappenas.go.id

Supported by Indonesian Development Planners Association (PPPI) 


\section{Introduction}

Trade liberalization and its effects are a major and debatable issue in many countries, including Indonesia. It is like a double-edged sword. Besides creating opportunities to promote economic growth, trade liberalization can also pose severe challenges for industries in the domestic market. According to previous literature, there are two core outlooks on this issue. The first view is that trade openness contributes to poverty alleviation in developing countries. This is because increasing demand for unskilled labor leads to higher workers' real wages; therefore, it is beneficial for poor workers. On the other hand, critics argue that the advantages of trade liberalization are not enjoyed equally within the countries.

Since 1980, Indonesia has experienced massive trade liberalization involving the first decline in the average line of tariffs and a slow tariffication of non-tariff barriers at the same time. The fiscal and financial policy reform accompanied this change, such as the improvement of tax efficiency and financial deregulation. Afterward, Indonesia passed through the next phase of trade reform that began in the early 1990s, which was marked by two momentous occasions. At the end of the Uruguay Round Agreement Acts, Indonesia committed to lowering its tariffs on all of its tradable products within the next ten years. Due to the East Asian economic crisis in 1997, Indonesia was recommended by the WTO to reduce its tariffs as a recovery process. The Indonesian economy began to stabilize after the crisis in 2000. However, import tariffs continued to decline even though the reduction was not as substantial as before (Amiti \& Konings, 2007).

Poverty is a major problem in Indonesia; thus, the government has put a great deal of effort into reducing the poverty rate. According to Statistics Indonesia (BPS) figures, the poverty rates have had a downward trend in recent years, which has decreased gradually. The proportion of the population in Indonesia that live under the poverty line in 2018 was $9.74 \%$, which was a slight decrease compared to the previous year, which was $10.38 \%$. It is found that the main source of reduction in poverty in most countries is economic growth. Most economists believe that economic growth benefits nearly all citizens of a country, if not equally, at least in reducing poverty. In Indonesia, it is presumed that there was an increase in employment opportunities during periods of high and sustained economic growth.

Several researchers have presented various studies about trade liberalization and poverty in Indonesia over the last decade. Some of them use Trade Openness Ratio as a measurement approach for free trade (Adha, Nahar, \& Azizurrohman, 2018) and Tambunan (Tambunan, 2008). Besides, some studies use tariff exposure to measure trade liberalization. This is because tariffs or non-tariff barriers are more relevant to trade liberalization policy. Recently, researchers are not only looking at changes in the simple average tariff within the period of analysis. Those studies also aim to investigate the differences in tariffs, combined with information on production structure between tradable sectors in each region. This is exemplified in the study undertaken by Kis-Katos \& Sparrow (2015), which investigates the effect of trade openness measured by tariffs across industries on Indonesia's poverty.

Like Topalova (2010), Kis-Katos \& Sparrow (2015) distinguish tariffs on output products and intermediate inputs by creating an alternative measurement that reflects the structures of regional sectoral input based on national input-output. They report that poverty and tariff exposure in output products have a negative correlation. Conversely, poverty and tariffs of intermediate products are positively correlated.

However, there is a possibility that the measurement of regional exposure for input tariffs is biased. Kis-Katos \& Sparrow (2015) use a national input-output table to compute regional exposure to input tariffs. Nonetheless, the economic structure of the region in Indonesia is contradictory. Therefore, to eliminate the possibility of biased results, this study uses regional (provincial) input-output tables to compute regional tariff exposure. The measurements of regional tariff exposure are used to explore how international trade affects regional poverty levels in Indonesia during the period from 2000 to 2016 at the regional level. 


\section{Methodology}

\subsection{Theoretical Framework}

Existing literature has revealed the main transmission channels that explain the linkages between trade liberalization and poverty, economic growth, government, markets, and employment (Winters \& Martuscelli, 2014). Firstly, trade liberalization could affect the incomes of the poor through an increase in economic growth. Notably, technology transfers due to imports and foreign investment are expected to generate aggregate income.

Secondly, the trade liberalization and poverty nexus involve government income and expenditure. Trade liberalization leads to a decline in government revenue, which in turn affects the direct transfers to the poor. Moreover, the government can use trade taxes as a source available for poverty reduction programs (Naranpanawa, Bandara, \& Selvanathan, 2011).

Thirdly, the effects of trade liberalization on poverty are linked through the substitution and income effects. Changes in prices generated by trade liberalization affect both nominal and real household incomes. Based on the Stolper-Samuelson theory, the imposition of tariffs increases the price of an item (Goldberg \& Pavcnik, 2005) and vice versa. Tariff reduction can cause the price of imported goods and goods that compete with imported goods to become relatively low. Consequently, goods that compete with imported goods go unsold in the market. Furthermore, industries that produce goods that compete with imported goods must reduce the price of their goods to compete and survive in the market. Then this item price factor will further influence decisions in households. If the price of goods decreases, the household will increase the consumption of the goods (demand for goods increases). It also has an impact on increasing labor demand so that wages will increase.

The relationship of trade liberalization to income distribution, in the long run, is well also explained in the Stolper-Samuelson model, based on the Hecksher-Ohlin neoclassical trade model. This theory can be intuitively explained as follows. Trade liberalization increases the income of relatively abundant production factors. Conversely, it decreases the income of relatively scarce production factors. That is, the owners of abundant factors of production will benefit from trade liberalization, while the owners of rare factors of production will suffer losses (Appleyard, Field, \& Cobb, 2006). In developing countries, the abundant resource factor is unskilled labor. Under these conditions, falling prices on imported intermediate goods in developing countries will cause an increase in industrial output that intensively uses unskilled labor (an abundant factor), thereby increasing demand and wages of unskilled labor (Goldberg \& Pavcnik, 2005; McCulloch, Winters, \& Cirera, 2002). Therefore, the relationship between prices and wages will be negative according to the Stolper-Samuelson argument. In short, in relatively unskilled labor-abundant countries, trade liberalization will reduce poverty; not all developing nations fall into this class.

Kis-Katos \& Sparrow (2015) explain the impact of trade liberalization on poverty through employment channels. It can be inferred that competition in the domestic market will increase when the government reduces import tariffs in a sector, which means the prices of imported products in that sector become cheaper. Local firms that experience increased competition will respond to falling prices for imported products by lowering their product prices. They, thus, will be able to compete with cheaper imported products in the domestic market. This price reduction leads firms to reduce their demand for labor because the value of extra output produced by hiring one more unit of labor will decrease. The number of vacancies posted by the firms will decline, which means market tightness in the sector will also decrease. The decrease in market tightness causes a higher possibility of someone being unemployed. Thus, the unemployment rate in the sector is increasing (Hasan, Mitra, Ranjan, \& Ahsan, 2012). Nuryitmawan (2020) states that unemployment is a key determinant of poverty. Being unemployed leads to the reduction of the standard of living due to reduced income. With a multisector model, it can be concluded that the reduction in import tariffs has an impact on increasing unemployment in sectors where firms experience competition with imported products on the domestic market (competing sectors of imports). In other words, a reduction in tariffs will have an impact on increasing poverty. Tariffs, in this case, are output tariffs.

Nevertheless, import tariffs cannot only have an impact on firms experiencing competition with imported products in the domestic market. Import tariffs can also affect firms using imported products as input in their production. These local firms experience cost advantages because of lower input costs, in this case, input tariffs. A decrease in input tariffs can increase profits for local firms that use imported products as production inputs. The increased profits can encourage firms to expand their 
businesses. The business expansion enables the firms to increase their demand for labor, which means employment is increasing. Under the assumption of free entry conditions, increased profits can also attract new firms to enter the domestic market, so that job creation occurs. The demand for labor increases so that employment ultimately increases. Increased profits due to lower input costs can also encourage firms to increase wages paid to their workers. In this case, the firms have increased productivity, so they are willing to pay higher wages for their workers. Thus, the impact of input tariff liberalization is negatively correlated to wages. This means that trade liberalization measured by tariff reduction has a positive relationship with poverty rates. Any empirical analysis of the trade liberalizationpoverty link depends on input and output tariffs related to domestic firms' competitiveness and employment.

One method to measure tariff exposure from the national level to the measurement of tariff exposure at the regional level is proposed by Topalova (2007). Topalova uses a method of regional tariff exposure in the form of a weighted sum of tariffs of each tradable sector product in an area, namely agriculture, mining, and manufacturing. This measurement utilizes the share of labor from each tradable sector to the total workforce in the initial period of each research observation. The calculation method is as follows:

Tariff $_{k, t}=\frac{\Sigma_{s} \text { Worker }_{s, k, t_{0}} * \text { tariff }_{s, t}}{\text { TotalWorker }_{k, t_{0}}}$

Where $s$ is the tradable sector, $k$ is the district, $t_{0}$ is the initial year of research observation, Tariff $_{k, t}$ is the import tariff of the product in sector $k$ in year $t$, orker $_{s, k, t_{0}}$ is the number of labor in the sector $s$ district $k$ in the year $t_{0}$, and the TotalWorker $k, t_{0}$ is the total workforce in district $k$ in the year $t_{0}$.

The measurement of regional tariff exposure in equation (1) uses the weight of labor share in each workforce's tradable sector. However, the use of these weights is assumed to cause high sensitivity to the allocation of workers who work in non-tradable sectors, which can cause the estimation results to be spurious. Therefore, Topalova (Topalova, 2007) provides an instrument for this measure, which is TrTariffk, defined as:

$\operatorname{TrTariff}_{k, t}=\frac{\Sigma_{s} \text { Worker }_{k, s, t_{0}} * \operatorname{tariff}_{s, t}}{\Sigma_{s} \text { Worker }_{k, s, t_{0}}}$

This measure is a non-scaled tariff that ignores labor in the non-tradable sector while Tariff $f_{k, t}$ is a scaled tariff. The measurement of regional tariff exposure proposed by Topalova (Topalova, 2007) is followed by many other studies that also examine the impact of trade liberalization at the regional level. An example of this is the study by Hasan, which investigates the impact of trade liberalization in India on unemployment at the state level. Another example is research conducted by Edmonds, Pavcnik, \& Topalova (2010), which shows the impact of trade liberalization on children's decisions going to school and working in India.

While Topalova (2007) uses labor share as the weights, Krisztina Kis-Katos \& Sparrow (2011) introduce different weights to measure regional tariff exposure in their research, examining the relationship between trade liberalization and child labor in Indonesia at the district level. Krisztina KisKatos \& Sparrow (2011) use the share of sectoral GRDP as a weighting in measuring regional tariff exposure, arguing that differences in economic structure between regions differ not only in terms of the composition of the workforce but also from the total output. This measurement method also ignores nontradable sectors. The alternative calculation method for regional tariff exposure is as follows:

$\operatorname{TrTariff}_{k, t}=\sum_{s}\left(\frac{G R D P_{s, k, t_{0}}}{G R D P_{k, t_{0}}} * \operatorname{Tariff}_{s, t}\right)$

Where $s$ is the sector, $k$ is the district, $t_{0}$ is the initial year, GRDP $P_{s, k, t_{0}}$ is the GRDP of the sector $s$ in the district $k$ in the initial year of observation, $G R D P_{k, t_{0}}$ is GRDP of district $k$ in the initial year of observation, and $\operatorname{TrTarif} f_{k, t}$ is the tariff in district $k$ in year $t$.

In a subsequent study of the effect of trade liberalization on poverty and the labor market in Indonesia, Kis-Katos \& Sparrow (2015) use the information on regional employment share to measure regional tariff exposure at the district level. Afterward, the calculation distinctions between tariffs on output products and the tariff on intermediate inputs, following the ideas of Amiti \& Konings (2007). Information on the output structure is obtained from the Large and Medium Manufacturing Survey, 
whereas the input structure is obtained from the Input-Output (I-O) table. The methods for calculating regional tariff exposure for output products and intermediate inputs are as follows:

OutputTariff $_{k, t}=\sum_{s}\left(\frac{Q_{s, k, t_{0}}}{Q_{k, t_{0}}} *\right.$ Tariff $\left._{s, t}\right)$
InputTariff $_{k, t}=\sum_{s}\left(\frac{Q_{s, k, t_{0}}}{Q_{k, t_{0}}} * \sum_{j}\left(\frac{M_{j, s, t_{0}}}{M_{s, t_{0}}} *\right.\right.$ Tariff $\left.\left._{j, t}\right)\right)$

where $s$ is the output sector, $j$ is the input sector, $k$ is the district, $t_{0}$ is the initial year, $Q_{s, k, t_{0}}$ is the sector output $s$ in the district $k$ in the initial year, $M_{j, s, t_{0}}$ is the input $j$ of the output $s$ in the initial year, $Q_{k, t_{0}}$ is the total output in the district $k$ in the initial year $t_{0}, M_{s, t_{0}}$ is the total input of output $s$ in the initial year, Tariff $f_{s, t}$ is the product tariff in the $s$ sector in $t$, and $\operatorname{Tariff}_{j, t}$ is the tariff of input $j$ in year $t$. In this study, they also do not include the non-tradable sector in calculating regional tariff exposure.

\subsection{Data and Methodology}

Following Topalova (2007) and Kis-Katos \& Sparrow (2015), the size of regional tariff exposures is a weighted sum of the tradable sector tariffs in an area. Weight is calculated based on employment share in a tradable sector from the total workforce in a region. This method captures differences in the level of exposure through differences in the structure of production in an area based on labor allocation. The weight of a tradable sector's tariffs will be higher if the sector has a relatively more labor allocation. The following calculation obtains the value of the tariff exposure of a district:

OutputTariff $f_{k t}=\sum_{s=1}^{s=30}\left(\frac{L_{s k, t=0}}{L_{k, t=0}} x\right.$ Tariff $\left._{s t}\right)$

Where $s$ is output sector, $k$ is a district, $\mathrm{t}=0$ is initial period, $L_{s k, t=0}$ is the employment of the output sector $s$ of district $k$ in the initial period, $L_{k, t=0}$ is the total labor force of district $k$ in the initial period, Tariff $_{\text {st }}$ is product tariff in the sector in year $t$.

The value of the regional tariff exposure at the district level is expected to illustrate the level of sensitivity to trade liberalization at the district level. The higher the value of regional exposure of a district, the more sensitive it is to reduce import tariffs due to trade liberalization. In other words, these districts experience greater trade reforms.

There are two steps of preparation before calculating regional tariff exposure at the district level. The first step is grouping the tradable sectors. In this study, products are classified into 30 tradable sector groups (including agriculture, mining, and manufacturing) based on International Standard Industrial Classification (ISIC) Rev. 3 at the 2-digit level. This aims to match with labor affiliation sectors that are available in Sakernas. Therefore, it requires a concordance from Harmonized System at the 6digit of WITS tariff data to the ISIC rev 3 classification at 2-digit level. Details of the 30 sectors used in this study are as follows:

Table 1. Tradable Sector Groups Based on ISIC Rev. 3 at 2-Digit level

\begin{tabular}{|c|l|}
\hline $\begin{array}{c}\text { ISIC } \\
\text { Code }\end{array}$ & \\
\hline $\mathbf{0 1}$ & Agriculture, Plantation, and Hunting \\
\hline $\mathbf{0 2}$ & Forestry and Logging \\
\hline $\mathbf{0 5}$ & Fishery \\
\hline $\mathbf{1 0}$ & Coal and Lignite Mining \\
\hline $\mathbf{1 1}$ & Crude Petroleum, Natural Gas, and Geothermal \\
\hline $\mathbf{1 2}$ & Uranium and Thorium Ore Mining \\
\hline
\end{tabular}




\begin{tabular}{|c|c|}
\hline 13 & Iron Ore Mining \\
\hline 14 & Other Mining and Quarrying \\
\hline 15 & Manufacture of Food Products and Beverages \\
\hline 16 & Manufacture of Tobacco Products \\
\hline 17 & Manufacture of Textiles \\
\hline 18 & Manufacture of Wearing Apparel \\
\hline 19 & Manufacture of Leather and Related Products and Footwear \\
\hline 20 & Manufacture of Wood and of Products of Wood \\
\hline 21 & Manufacture of Paper and Paper Products \\
\hline 22 & Printing and Reproduction of Recorded Media \\
\hline 23 & Manufacture of Coal and Refined Petroleum Products \\
\hline 24 & Manufacture of Chemicals and Pharmaceuticals and Botanical Products \\
\hline 25 & Manufacture of Rubber, Rubber Products, and Plastics Products \\
\hline 26 & Manufacture of Other Non-Metallic Mineral Products \\
\hline 27 & Manufacture of Basic Metals \\
\hline 28 & Manufacture of Fabricated Metal Products, Except Machinery and Equipment \\
\hline 29 & Manufacture of Machinery and Equipment \\
\hline 30 & Manufacture of Office, Accounting, and Computing Machinery \\
\hline 31 & Manufacture of Electric Machinery and Apparatus \\
\hline 32 & Manufacture of Radio, Television, and Communication Equipment and Apparatus \\
\hline 33 & Manufacture of Medical, Precision, and Optical Instruments, Watches, and Clocks \\
\hline 34 & Manufacture of Motor Vehicles, Trailers and Semi-Trailers \\
\hline 35 & Manufacture of Other Transport Equipment \\
\hline 36 & Furniture and Other Manufacturing \\
\hline
\end{tabular}

Note. Adapted from Statistics Indonesia (BPS)

The calculation of regional tariff exposure at the district level in this study does not include nontradable sectors. Kovak (2013) shows in his study that prices of non-tradable goods moved simultaneously with prices of tradable goods during liberalization. Hence, the non-tradable sector could be ignored in calculating regional tariff exposure at the regional level. The result of the calculation of import tariffs is called output tariffs.

Subsequently, the information on output tariffs is used to calculate the intermediate input tariffs with the average method. Information about the weighted average input of a product is obtained from the 2000 use table, which is controlled with a more aggregate level using the 2000 Input-Output Table for each province. 
For computing input tariff, the calculation is given as follows:

InputTarif $f_{k t}=\sum_{s=1}^{s=30}\left(\frac{L_{s k, t=0}}{L_{k, t=0}} x \sum_{j=1}^{J}\left(\frac{M_{j s, t=0}}{M_{s, t=0}} x\right.\right.$ Tarif $\left.\left._{j t}\right)\right)$

Where $s$ is output sector, $j$ is input sector, $k$ is district, $\mathrm{t}=0$ is initial period, $L_{s k, t=0}$ is the employment of the output sector $s$ of district $k$ in the initial period, $L_{k, t=0}$ is the total labor force of district $k$ in the initial period, $M_{j s, t=0}$ is input $j$ from output $s$ in the initial period at the province level, $M_{s, t=0}$ is input total from output $s$ in the initial period at the province level, Tarif $f_{j t}$ is the tariff of input product $j$ in year $t$.

This study employs the fixed effect estimation method to reach its purpose, and the model is as follows:

$y_{k, t}=\beta_{0}+\beta_{1}$ OutputTarif $f_{k, t-1}+\beta_{2}$ InputTariff $f_{k, t-1}+\sum_{t=1}^{3} \delta_{i} X_{i, k, t}+\alpha_{k} \varepsilon_{k, t}$

Where $y_{k, t}$ is poverty headcount index (P0) varied by $k$ districts and $t$ time, OutputTarif $f_{k, t-1}$ is regional exposure for output products varied by $k$ districts and $t-1$ time. InputTariff $f_{k, t-1}$ is regional exposure for intermediate inputs by $k$ districts and $t-1$ time. $\beta_{0}, \beta_{1}$, and $\beta_{2}$ are parameters of the fixedeffect model. $X_{i, k, t}$ is a vector of other control variables (log of GRDP per capita, literacy rate, and road length) varied by $k$ districts and $t$ time, $\varepsilon_{k, t}$ is error term of district $k$ at year $t$.

To test the hypotheses, this study uses panel data with districts in Indonesia as cross-section units analyzed during the period from 2000 to 2016. Panel data helps to identify the differences in the impact of trade liberalization on poverty between districts. Districts (regencies or municipalities) used as the unit of analysis in this study are based on the administrative condition of the regions in the year 2000, which amounted to 303 districts. New districts which emerged after the year 2000 due to the proliferation of administrative regions will be returned to their parent or initial districts. The issue of regional proliferation is an important concern in regional analysis in Indonesia because most districts in Indonesia experience proliferation and generate new districts.

To calculate the poverty headcount index (PO) for initial districts, this study requires information about the number of poor people and the population of each new district that emerged. By dividing the total population of the poor with the total population into the initial districts, the poverty headcount index (P0) for each original district can be obtained. Furthermore, the poverty gap index (P1) and poverty severity index (P2) measurements for original districts require poverty line and household expenditure information. Due to the lack of this information, this study cannot involve the poverty headcount index (P1) and poverty severity index (P2).

The data on employment in 2000 are required for the calculation of regional tariff exposure. However, there are missing data on employment in several districts in 2000. Therefore, the districts experiencing missing data are not involved in the analysis, including Aceh Selatan, Maluku Tenggara, Maluku Tengah, Maluku Utara, Halmahera Tengah, and the City of Ambon. The total remaining districts that become the unit of analysis in this study are 297 districts.

In terms of variables, this research requires several data. First, information regarding tariffs comes from the UNCTAD-TRAINS database, which is retrieved from the WITS website. The sectors involved in the analysis of this study are 30 tradable sectors covering agriculture, mining, and manufacturing. Second, data of poverty measurements are obtained from Statistics Indonesia, which annually publishes the data of the poverty headcount index (PO). Third, data regarding regional employment share, which are involved in computing regional tariff exposure, are sourced from Sakernas (the annual labor force survey). Information on the allocation of labor in a certain tradable industry in each district or city is obtained by calculating the ratio. Information on the number of workers in each district is obtained from the Sakernas data of 2000. These data of Sakernas are not representative for estimates at the district level. Hence, the calculation of the aggregate data uses the inflation factor, which is available in the data. Fourth, information about the weighted average input of a product is obtained from the Input-Output Table 2000 for each province. The measurement of input tariffs in this study is carried out by calculating the weighted average of the output tariffs. In line with Kis-Katos \& Sparrow (2015), this study uses weight based on the input structure in the Input-Output Table 2000. The use of the 2000 input structure is deemed appropriate because the year 2000 is the initial year of this research 
period. According to the measurement proposed by Amiti and Konings (Amiti \& Konings, 2007), regional input tariffs calculation uses the input structure of the initial period. Also, the intermediate input structure used in a region is assumed not to change in the short term. Also, the updated IO table after 2000 is not yet available in all provinces.

Moreover, Gross Regional Domestic Product (GRDP) per capita, literacy rate, road length are used as control variables in this study. Data for these variables have been taken from Statistic Information Books published by Statistics Indonesia.

\section{Results and Discussion}

This study uses data from Statistics Indonesia (BPS) in 2000-2017 to conduct a descriptive analysis of poverty rates in Indonesia. As a basis for measuring poverty, BPS uses the concept of a person's ability to meet basic needs. With this approach, poverty is seen as an inability from the economic side to meet basic food and non-food needs measured from the poverty line. Thus, the poverty headcount index (P0), the percentage of the population under the poverty line, can be calculated. As previously explained in Research Methodology Chapter, the poverty line method consists of two components: the food poverty line and the non-food poverty line. Hence, the poor are residents who have an average monthly expenditure per capita below the poverty line. Indonesia's national poverty line was set at consumption outlays of Rp. 374,477- per month per person, while the latest Indonesia's national poverty line was recorded at Rp. 425,250,- in 2019.

The advantage of the poverty headcount index is that it is easy to calculate and easy to understand. However, this indicator has several weaknesses: the headcount index does not consider the intensity of poverty, does not indicate how poor the poor are, and does not change if people below the poverty line become poorer. Despite the percentage of poor households, the poverty headcount index measures the percentage of poor individuals. For the percentage of households to apply, an assumption is made that all household members enjoy the same welfare level. However, in reality, not all consumption is shared equally among all household members.

The development of poverty levels in Indonesia in the period 2000-2017 is shown in Figure 1. In the period 2000-2005, there was a declining trend, although the number of poor people in 2002 experienced a slight increase compared to 2001. The reduction in poverty levels occurred again during the 2006-2013 periods. During this period, the number of poor people decreased by 6.38 million people, from 39.30 million people in 2006 to 28.07 million people in 2013. In absolute terms, the percentage of the poor population decreased from $17.75 \%$ in 2006 to $11.37 \%$ in 2013. Furthermore, in 2014 the number of poor people increased and reached 28.59 million people in 2015. Afterward, it dropped to 27.7 million people in 2017. However, in relative terms, the percentage of poverty fell steadily in the final years to $10.64 \%$ in 2017.

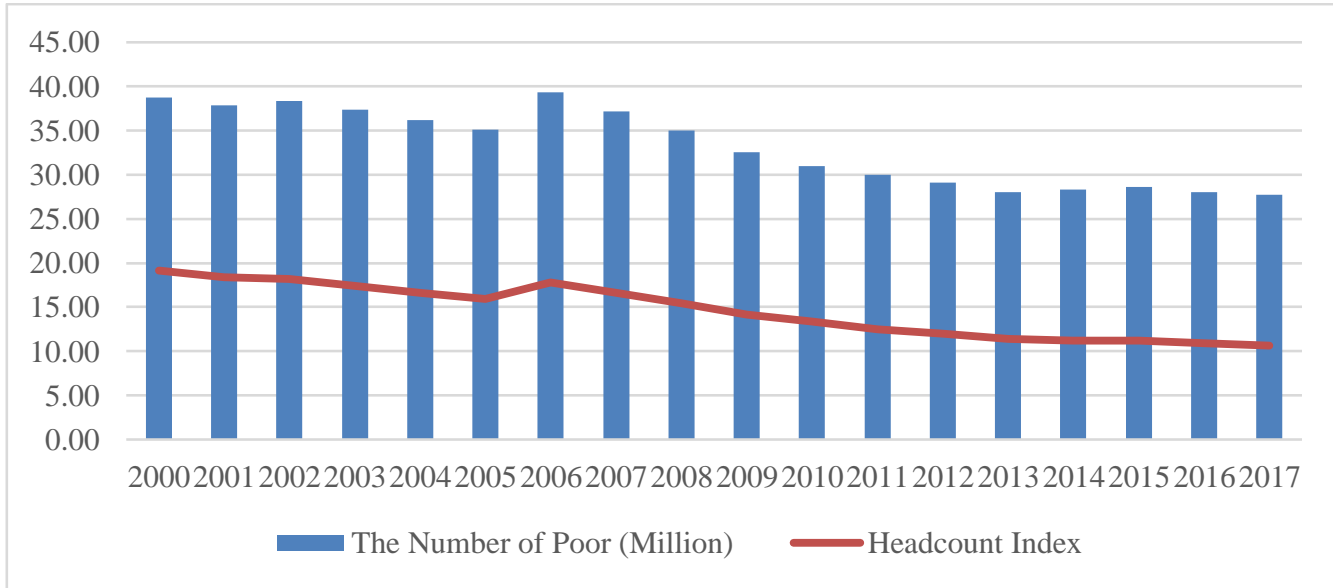

Figure 1. The Number and Percentage of People Living in Poverty Indonesia, 2000-2017 Source: Statistics Indonesia (BPS)

There were three factors driving poverty reduction at the end of the period of analysis. First, inflation was maintained within the stable target range of $4 \%$ plus $1 \%$. The government was considered 
to be successful in maintaining price stability, especially in the food component. The second was the increase in real agricultural wage rates in rural areas, and third, the integration of poverty alleviation programs (Zuhdiyaty \& Kaluge, 2018).

Table 2 shows the variation in regional tariff exposure by island. Generally, the average regional tariff exposure in all regions in the 2000-2008 period tends to increase. To overcome the surge in import flows into the domestic market in the period 2004-2008, the government felt the need to implement a trade security policy through AntiDumping Duty. Therefore, it is seen that the government is more inclined to make Indonesia's foreign trade policy move towards a protective direction by increasing import tariffs. Several industries experienced tariff increases during the period 2000-2008, for example, food and beverages (from $6.76 \%$ to $14.23 \%$ ), textiles (from $7.51 \%$ to $9.67 \%$ ), wearing apparels (from $10.05 \%$ to $14.09 \%$ ), chemicals, and pharmaceuticals, and botanical products (from $8.84 \%$ to $4.80 \%$ ), and basic metal (from $5.45 \%$ to $6.57 \%$ ).

Table 2. Average Regional Tariff Exposure in Indonesia, 2000-2016

\begin{tabular}{|l|l|l|l|l|l|}
\hline \multicolumn{1}{|c|}{ Island } & $\mathbf{2 0 0 0}$ & $\mathbf{2 0 0 4}$ & $\mathbf{2 0 0 8}$ & $\mathbf{2 0 1 2}$ & $\mathbf{2 0 1 6}$ \\
\hline Sumatera & 4.120 & 4.666 & 5.930 & 2.629 & 1.843 \\
\hline Java & 4.815 & 5.172 & 6.967 & 3.187 & 2.309 \\
\hline Bali and Nusa Tenggara & 4.275 & 4.729 & 6.136 & 2.640 & 1.964 \\
\hline Kalimantan & 3.855 & 4.247 & 5.308 & 2.063 & 1.726 \\
\hline Sulawesi & 4.175 & 4.864 & 6.129 & 3.083 & 1.816 \\
\hline Papua & 3.547 & 3.847 & 4.883 & 1.678 & 1.476 \\
\hline
\end{tabular}

Source: WITS, data is processed

Moreover, the greatest increase in the average regional tariff exposure occurred in Java Island compared to other regions in Indonesia. This could be attributed to industries that experienced increased tariffs and absorbed much of the labor force located on Java Island, such as food products and beverages, tobacco products, textiles, wearing apparel, motor vehicles, trailers, and semi-trailers companies. Over the period of 2012-2016, the islands that had the largest decreases in regional tariff exposure to the global economy were Sulawesi and Java, followed by Sumatera, and Bali, and Nusa Tenggara.

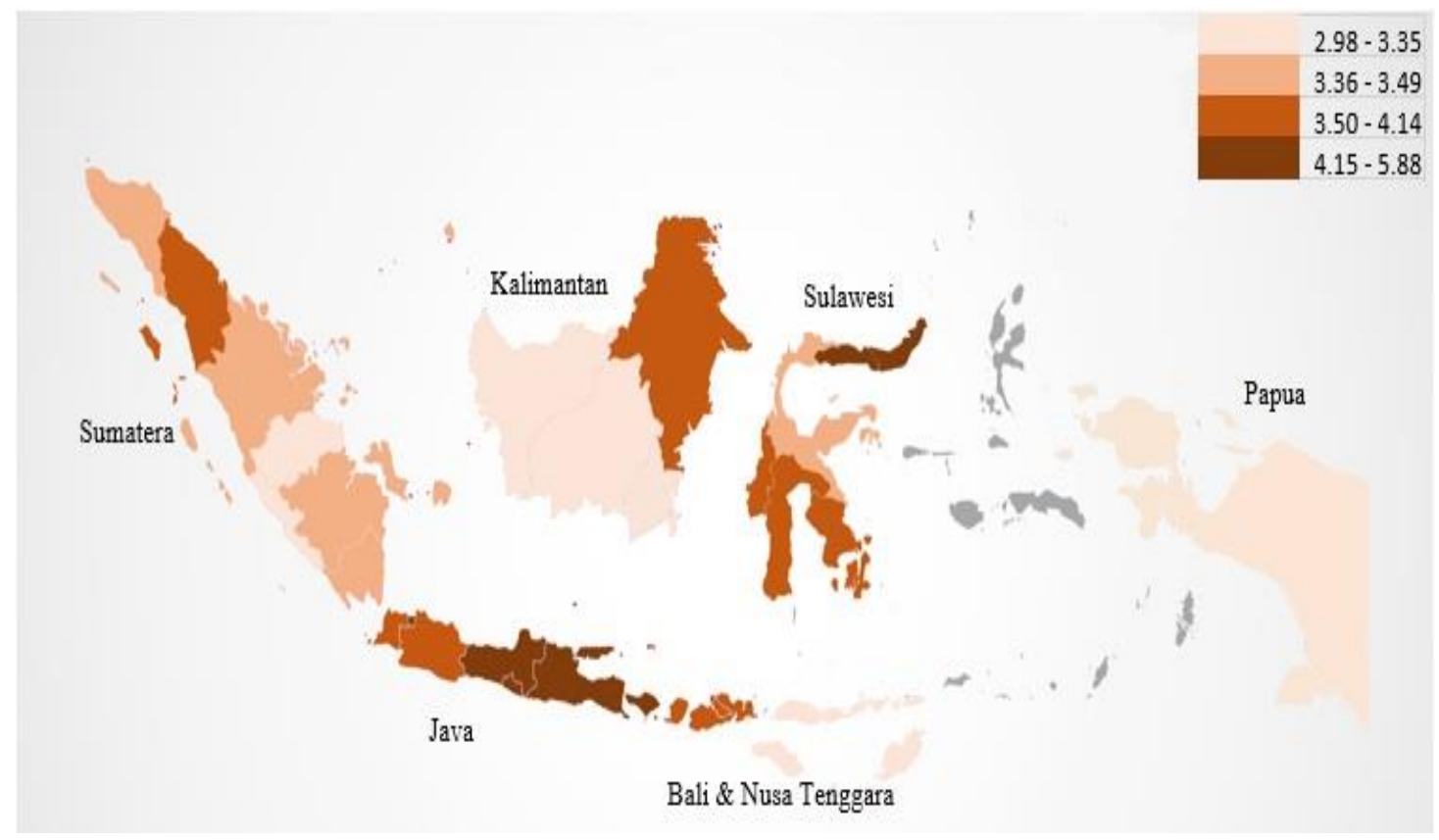

Figure 2. Regional Tariff Exposure for Output Products in Indonesia (2000-2016) Source: Statistics Indonesia and UNCTAD-TRAINS, processed

Furthermore, the City of Kediri, Kudus Regency, and the City of Manado have the highest average regional tariff exposure than other districts during the 2000-2016 period. These regions have more tradable sector compositions than other regions. It can be inferred that these regions with high 
regional tariff exposure are more sensitive to import tariffs. Conversely, the region with the lowest average regional tariff exposure is Papua. It implies that districts in the Papua region are less sensitive to changes in import tariffs. Mimika Regency and Merauke Regency have the lowest average regional tariff exposure compared to other districts during the 2000-2016 period.

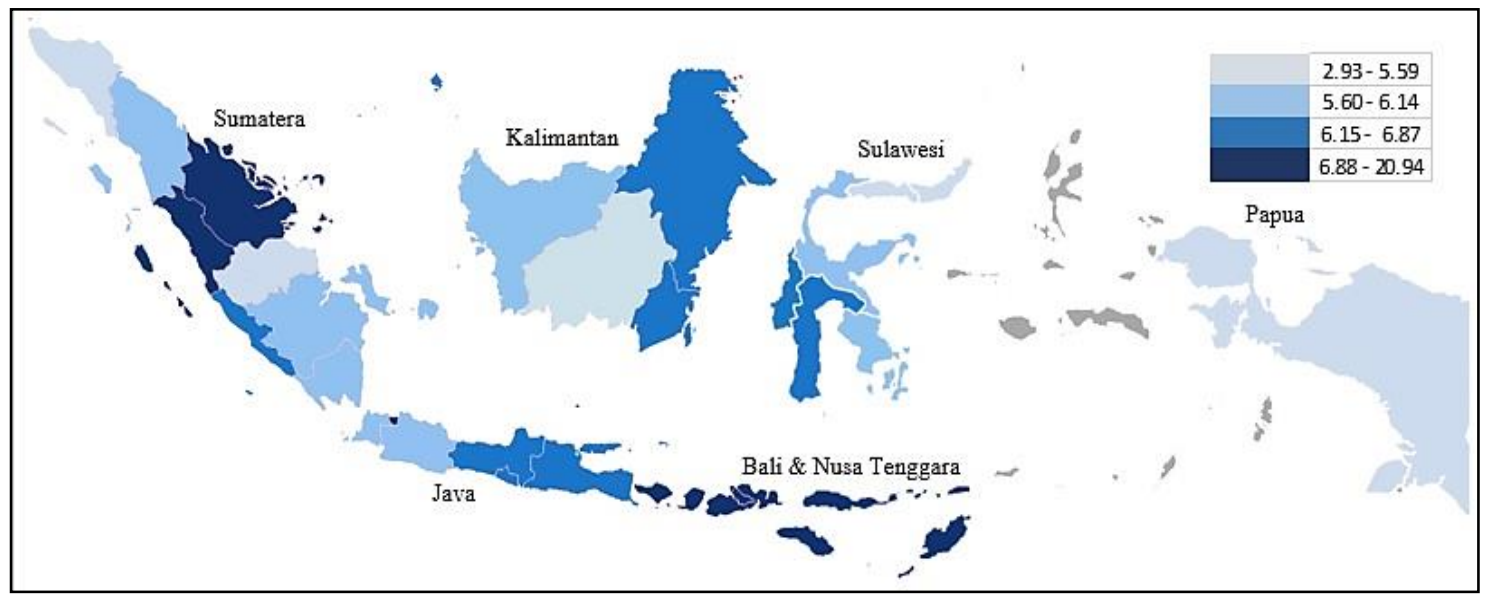

Figure 3. Regional Tariff Exposure for Intermediate Inputs in Indonesia (2000-2016) Data Source: Statistics Indonesia and UNCTAD-TRAINS, processed

Figure 3 maps the variation of regional tariff exposure for intermediate inputs. The districts more sensitive to input tariffs are located in Jakarta, Sumatera Barat, Riau, and Bali, and Nusa Tenggara. Input tariff indicates the sensitivity of a district to tariffs on imported goods used as intermediate inputs in the local industries. High input tariffs indicate that the component of industrial products in a district are mostly products with high import tariffs and vice versa. Low input tariffs imply that industries in districts do not depend on imported intermediate inputs with high tariffs.

The regression results of the fixed effects model are reported in Table 3. Column (1) revealed that the results of basic regression specification indicate that import tariffs, both of output products and intermediate inputs, are associated with poverty rates at the district level. The coefficient estimates that output tariffs and input tariffs are both statistically significant and positive, suggesting that a reduction in tariff exposure leads to a decrease in poverty rates. The next step is to add year-fixed effects.

Table 3. Estimated Results of the Impact of Trade Liberalization on the Poverty Rates (Fixed Effects Model)

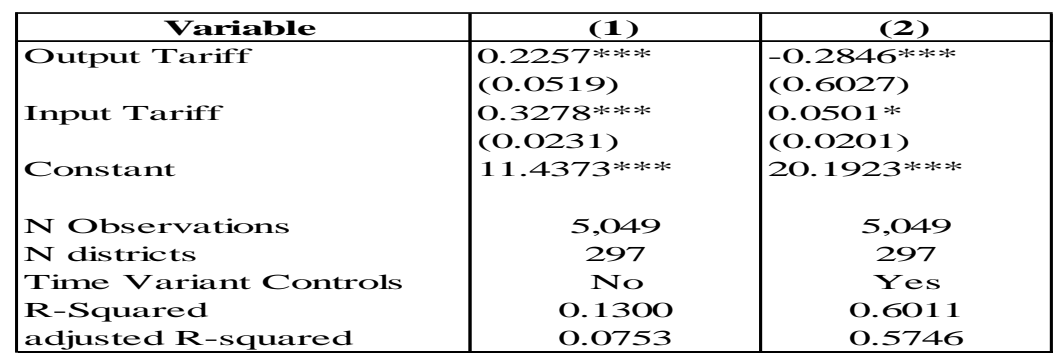

\footnotetext{
Note: Dependent variable is the poverty rate measured by the headcount index. All standard errors are robust and reported in parentheses.

* Significant at $10 \%$

$* *$ Significant at $5 \%$

*** Significant at $1 \%$
}

As shown in column 2 of Table 3, the result for the variable of output tariff completely reverses after controlling for year fixed effects. These primary results are consistent with the findings of Kis-Katos \& Sparrow (2015). Using the first difference specification, they establish that output tariffs have a strong and negative impact on poverty rates instead of input tariffs, which significantly and positively affect 
poverty rates in Indonesia. They also include the time effect in their model, which allows controlling timespecific fixed effects. Compared to the base regression in model (1), model (2) is relatively better here due to its control for national anti-poverty actions by the Indonesian government (Bhattacharyya \& Resosudarmo, 2015).

Column 2 of Table 3 shows that a fall in output tariffs of 10 percentage points increases poverty rates by 2.8 percentage points. This significant negative coefficient reveals that trade liberalization would increase competition in the output market in Indonesia. Attanasio, Goldberg, \& Pavcnik (2004) and Schor (2004) argue that the tariff reduction on output goods can affect competition between firms that produce the same product. When there is a reduction in the final goods tariff, firms seek to increase market share through increased efficiency. This certainly hurts local firms that have limited capital. Hence, firms may have reduced costs by recruiting temporary workers. They even terminated their workers to cover losses. This will result in households receiving reduced income. Ultimately, they cannot fulfill their daily needs, and poverty alleviation cannot be implemented.

Columns 1 and 2 of Table 3 report the coefficients of input tariff in these benchmarking regressions. Based on the estimation results of these models, the coefficient of input tariff is significant and positive. The positive coefficient indicates that input tariff reduction contributes to poverty reduction, even though relatively small. These results are in line with the findings in the study of Hasan et al. (Hasan et al., 2012). Their research suggests that a reduction in input tariffs can cause a decrease in the unemployment rate at the district level. Therefore, this will be beneficial for poverty reduction. These findings provide an insight into the positive correlation between input tariffs and poverty rates. The lower tariff for intermediate inputs causes a decrease in input costs. Firms will get more profit; thereby, the firms expand their businesses so that the firms' size is getting bigger. This can create employment and reduce poverty further.

To reduce the potential for spurious findings, control variables are included in this statistical model. Table 4 presents results using GRDP, literacy rates, and road length as the control variables. Similar to the previous basic model, the regression of these specifications is conducted, either by taking into account the year dummies or overlooking them. The results in column 3 and column 4 in Table 4 indicate that the main variables, output tariffs, and input tariffs, remain significant. However, taking into account the overall effects of control variables on poverty rates, it is found that the coefficients of output tariffs and input tariffs diminish. Table 4 also displays the results obtained from the analysis of control variables accounted for in this study. It is found that, as hypothesized, all control variables are significant and are negatively associated with poverty rates in Indonesia at the district level.

Table 4. Estimated Results of the Impact of Trade Liberalization on the Poverty Rates with Control Variables (Fixed Effects Model)

\begin{tabular}{|c|c|c|c|c|}
\hline Variables & (1) & (2) & (3) & (4) \\
\hline Output Tariff & $\begin{array}{l}0.2257 * * * \\
(0.0519)\end{array}$ & $\begin{array}{l}-0.2846 * * * \\
(0.6027)\end{array}$ & $\begin{array}{l}0.0188 * * \\
(0.0369)\end{array}$ & $\begin{array}{l}-0.1897 * * * \\
(0.0548)\end{array}$ \\
\hline Input Tariff & $\begin{array}{l}0.3278 * * * \\
(0.0231)\end{array}$ & $\begin{array}{l}0.0501 * \\
(0.0201)\end{array}$ & $\begin{array}{l}0.079 * * * \\
(0.0171)\end{array}$ & $\begin{array}{l}0.0422 * * \\
(0.0194)\end{array}$ \\
\hline Ln GRDP & & & $\begin{array}{l}-11.6759 * * * \\
(0.6290)\end{array}$ & $\begin{array}{l}-0.2119 * * * \\
(0.7482)\end{array}$ \\
\hline Literacy & & & $\begin{array}{l}-3.2047 * * * \\
(0.0175)\end{array}$ & $\begin{array}{l}-0.2175 * * * \\
(0.0162)\end{array}$ \\
\hline Road Length & & & $\begin{array}{l}-0.0002 * * * \\
(0.0000)\end{array}$ & $\begin{array}{l}-0.0001 * * * \\
(0.0000143)\end{array}$ \\
\hline Constant & $\begin{array}{l}11.4373 * * * \\
(0.1408)\end{array}$ & $\begin{array}{l}20.1923 * * * \\
(0.3311)\end{array}$ & $\begin{array}{l}57.9049 * * * \\
(1.3962)\end{array}$ & $\begin{array}{l}38.7645 * * * \\
(1.5466)\end{array}$ \\
\hline N Observations & 5,049 & 5,049 & 5,049 & 5,049 \\
\hline $\mathrm{N}$ districts & 297 & 297 & 297 & 297 \\
\hline Time Variant Controls & No & Yes & No & Yes \\
\hline R-Squared & 0.1300 & 0.6011 & 0.5057 & 0.6131 \\
\hline adjusted $\mathrm{R}$-squared & 0.0753 & 0.5746 & 0.4672 & 0.5837 \\
\hline
\end{tabular}

Note: Dependent variable is the poverty rate measured by the headcount index. All standard errors are robust and reported in parentheses.

* Significant at $10 \% * *$ Significant at $5 \% * * *$ Significant at $1 \%$

This study also investigates differential effects by each control variable. To see the difference in the impact of the import tariffs reduction for both final goods and intermediate inputs between districts, the variable of regional tariff exposure was lagged to interact with the control variables. Table 5 
presents estimated results considering the interaction of output tariffs with further control variables: GRDP, literacy rates, road length, and the input tariffs.

Model (i) shows that the interaction term of output tariffs and GRDP per capita on poverty rates is negative and statistically significant at $5 \%$. It indicates that the increase in output tariff results in a decline of the district level's poverty rates. Furthermore, the increase of output tariff leads to lower poverty in districts with higher GRDP per capita. The level of GRDP is a condition that high output tariff leads to lower poverty rates. This effect is transmitted through the higher price of imported goods, enabling households to increase the demand for domestic products. Firms thus promote their businesses and increase wages and, in turn, will benefit the region with higher GRDP per capita. This indicates that when there is an increase in tariffs on output products, districts with higher GRDP per capita will have lower poverty.

Model (iii) reports the estimated results of the interaction term between output tariffs and road length and are positive and statistically significant at $1 \%$. This means that the reduction in output tariffs increases poverty rates at the district level. Moreover, the reduction of output tariff leads to higher poverty in districts with lesser road length. When there is a decrease in output products, districts with poor access to markets will have higher poverty.

Table 5. Estimated Results of Interaction Terms of Output Tariffs and Input Tariffs with Other Control Variables (Fixed Effects Model)

\begin{tabular}{|c|c|c|c|c|c|c|}
\hline Variables & (1) & (2) & (3) & (4) & (5) & (6) \\
\hline Output Tariff & $\begin{array}{l}-0.2915 * * \\
(0.1005)\end{array}$ & $\begin{array}{l}-0.9780 * * \\
(0.3101)\end{array}$ & $\begin{array}{l}-0.4667 * * * \\
(0.0777)\end{array}$ & $\begin{array}{l}-0.3144 * * * \\
(0.0564)\end{array}$ & $\begin{array}{l}-0.1666^{* *} \\
(0.0552)\end{array}$ & $\begin{array}{l}-0.2031 * * * \\
(0.0549)\end{array}$ \\
\hline Input Tariff & $\begin{array}{l}0.0206 * * \\
(0.0214)\end{array}$ & $\begin{array}{l}0.0300^{*} \\
(0.0196)\end{array}$ & $\begin{array}{l}0.0556^{* * *} \\
(0.0195)\end{array}$ & $\begin{array}{l}0.10034 * * \\
(0.0261)\end{array}$ & $\begin{array}{l}0.4260^{* * * *} \\
(0.1128)\end{array}$ & $\begin{array}{l}0.02478 \\
(0.0254)\end{array}$ \\
\hline Ln GRDP & $\begin{array}{l}-1.7589^{* *} \\
(0.8422)\end{array}$ & $\begin{array}{l}-0.1828 \\
(0.7470)\end{array}$ & $\begin{array}{l}-0.2182 * * \\
(0.7460)\end{array}$ & $\begin{array}{l}-2.5174 * * \\
(0.8230)\end{array}$ & $\begin{array}{l}-0.1174 * * * \\
(0.7477)\end{array}$ & $\begin{array}{l}0.4061 \\
(0.7483)\end{array}$ \\
\hline Literacy & $\begin{array}{l}-0.2098 * * * \\
(0.0174)\end{array}$ & $\begin{array}{l}-0.1706 * * * \\
(0.0203)\end{array}$ & $\begin{array}{l}-0.2108 * * * \\
(0.0162)\end{array}$ & $\begin{array}{l}-0.2056 * * * \\
(0.0173)\end{array}$ & $\begin{array}{l}-0.1790 * * * \\
(0.0196)\end{array}$ & $\begin{array}{l}-0.2144 * * * \\
(0.0162)\end{array}$ \\
\hline Road Length & $\begin{array}{l}-0.0001 * * * \\
(0.0001)\end{array}$ & $\begin{array}{l}-0.0001 * * * \\
(0.0001)\end{array}$ & $\begin{array}{l}-0.0001 * * * \\
(0.0001)\end{array}$ & $\begin{array}{l}-0.0001 * * * \\
(0.0001)\end{array}$ & $\begin{array}{l}-0.0001 * * * \\
(0.0001)\end{array}$ & $\begin{array}{l}-0.0001 * * * \\
(0.0001)\end{array}$ \\
\hline Output Tariff*Ln GRDP & $\begin{array}{l}-0.0704 * * \\
(0.0758)\end{array}$ & & & & & \\
\hline Output Tariff*Literacy & & $\begin{array}{l}-0.01207 \\
(0.0032)\end{array}$ & & & & \\
\hline Output Tariff*Road Length & & & $\begin{array}{l}9.79 \mathrm{E}-06 * * * \\
(1.9500)\end{array}$ & & & \\
\hline Input Tariff*Ln GRDP & & & & $\begin{array}{l}0.1877 * * * \\
(0.039)\end{array}$ & & \\
\hline Input Tariff* Literacy & & & & & $\begin{array}{l}0.0045^{* * *} \\
(0.0013)\end{array}$ & \\
\hline Input Tariff*Road & & & & & & $\begin{array}{l}4.29 \mathrm{E}-06 \\
(1.0600)\end{array}$ \\
\hline Constant & $\begin{array}{l}37.7989 * * * \\
(1.6577)\end{array}$ & $\begin{array}{l}34.2269 * * * \\
(1.9471)\end{array}$ & $\begin{array}{l}39.0003 * * * \\
(1.5428)\end{array}$ & $\begin{array}{l}37.2359 * * * \\
(1.6495)\end{array}$ & $\begin{array}{l}35.3966 * * * \\
(1.8264)\end{array}$ & $\begin{array}{l}38.6397 * * * \\
(1.5440)\end{array}$ \\
\hline N Observations & 5,049 & 5,049 & 5,049 & 5,049 & 5,049 & 5,049 \\
\hline $\mathrm{N}$ districts & 297 & 297 & 297 & 297 & 297 & 297 \\
\hline Time Variant Controls & Yes & Yes & Yes & Yes & Yes & Yes \\
\hline R-Squared & 0.6030 & 0.6145 & 0.6155 & 0.6050 & 0.6143 & 0.6147 \\
\hline adjusted R-squared & 0.5705 & 0.5851 & 0.5861 & 0.5729 & 0.5848 & 0.5853 \\
\hline
\end{tabular}

Note: Dependent variable is the poverty rate measured by the headcount index. All standard errors are robust and reported in parentheses.

* Significant at $10 \%$

** Significant at $5 \%$

$* * *$ Significant at $1 \%$

In model (iv), it can be seen that the interaction term between input tariffs and GRDP per capita has a positive coefficient and is significant at $1 \%$. It can be inferred that the reduction in input tariffs decreases poverty rates at the district level. Furthermore, the reduction of input tariffs leads to lower poverty in districts of higher GRDP per capita. In districts with higher GRDP, the effects of input 
tariff reduction on poverty reduction are larger. Clearly, the level of GRDP shows that low input tariffs lead to lower poverty rates.

Furthermore, model $(v)$ reveals that the impact of interaction terms of input tariffs and literacy rate on poverty rates is positive and statistically significant at $1 \%$. This implies that the reduction in input tariff results in a decrease in poverty rates at the district level. Furthermore, the reduction of input tariffs leads to higher poverty in districts with higher literacy rates. Clearly, the level of literacy rates shows that low input tariffs lead to lower poverty rates.

Nevertheless, when the output tariff interacts with literacy rates, it is found that the interaction variable is not significant. This insignificance also happens in the interaction of input tariffs and road length.

\section{Robustness Check}

The general effects of trade liberalization on poverty for further specifications, following the first difference estimating equation by Kis-Katos \& Sparrow (2015), are shown in Table 6.

Table 6. Robustness Check Poverty Effects of Trade Liberalization (Fixed Effects Model)

\begin{tabular}{|l|c|l|l|}
\hline \multicolumn{1}{|c|}{ Variables } & \multicolumn{1}{|c|}{$(\mathbf{1})$} & $(\mathbf{2})$ & $(\mathbf{3})$ \\
\hline & & & \\
Output Tariff & 0.0909 & $-0.3172^{* * *}$ & $-0.3996^{* * *}$ \\
& $(0.0795)$ & $(0.0860)$ & $(0.1009)$ \\
Input Tariff & $0.0345^{*}$ & $0.0324^{* *}$ & $0.0303^{* *}$ \\
Ln GRDP & $(0.0344)$ & $(0.0317)$ & $(0.0325)$ \\
& & & \\
Literacy & & & \\
& & & \\
Road Length & & & \\
& & & \\
Constant & $-2.7124^{* * *}$ & $-1.1636^{* * *}$ & $-0.3638^{* * *}$ \\
& $(0.2747)$ & $(0.2732)$ & $(0.4390)$ \\
N Observations & 4,752 & 4,752 & 4,752 \\
N districts & 297 & 297 & 297 \\
Year-Island dummies & Yes & Yes & Yes \\
Time Variant Controls & No & Yes & Yes \\
Initial Labor Force & No & No & Yes \\
R-Squared & 0.024 & 0.3642 & 0.3545 \\
adjusted R-squared & 0.010 & 0.1473 & 0.1311 \\
\hline
\end{tabular}

Note: Each block of the table reports tariff coefficients, generated by first difference estimates of the reported dependent variables on tariffs and further controls. All standard errors are robust and reported in parentheses.

* Significant at $10 \%$

** Significant at $5 \%$

*** Significant at $1 \%$

The negative relationship between the poverty and output tariffs emerges after controlling the time-year-island dummies and time-variant controls, inferring that tariff reduction on output products is negatively associated with a poverty reduction. In contrast, under the initial conditions, the reduction in intermediate inputs is statistically significant and positively correlated with a poverty reduction. 
These results show that the relationship between poverty and regional tariff exposure, either for output products or intermediate inputs, is robust. Therefore, these findings provide additional evidence for the linkage between trade liberalization and poverty.

\section{Conclusion}

This study examines the linkages between trade liberalization and poverty. It particularly seeks to learn the effects of tariff reduction on the incidence of poverty at the district level in Indonesia from 2000 to 2016. This study assesses reductions in tariffs on imported goods as a whole and investigates the impacts of intermediate input tariffs, which are measured as a weighted average of the output tariffs based on the input-output table. Using the fixed effects model, the estimation results show that tariff exposure for intermediate inputs and final goods has the opposite effect by the theory. A reduction in output tariffs leads to a higher poverty rate. Conversely, a decrease in input tariffs generates a poverty reduction. These primary results prove the main hypotheses of this study.

Expanding the model with further controls, it is found that GRDP per capita, literacy rates, and road length are negatively correlated with poverty rates. These findings thus support the hypotheses that the increase of these control variables (GRDP per capita, literacy rates, and road length) leads to reductions of the poverty rates.

Moreover, the benefits of reducing input tariffs to reduce poverty are larger in districts that have higher GRDP per capita and higher literacy rates. These findings are attributed to the fact that the interaction variable between input tariffs and GRDP per capita is significant and the interaction variable between input tariffs and literacy rates.

These findings have important implications for alleviating poverty and enhancing economic performance. Policymakers need to thoughtful when determining the import tariffs because different effects on poverty rates are observed. When a tariff is used to protect a sector or an industry, it could increase the costs in other sectors or industries. Imported goods are not only used as final consumption but also as intermediate inputs for local firms. Thus, the government should consider the differential effects of reducing input and output tariffs when promoting trade liberalization. Trade liberalization, especially input tariff reduction, could be more beneficial to the poor because it can increase employment and reduce poverty.

The results of tariff exposure for intermediate inputs indicate that Indonesia depends on imported intermediate inputs to a relatively high degree. It might be better for the government to establish policies that are expected to encourage firms to adjust their production patterns to use more domestic inputs as they would be more efficient. To sum up, maintaining an openness to trade, but not only in input goods, and the effort to develop domestic industries should be a crucial part of Indonesian growth strategy.

\section{Acknowledgments}

I gratefully acknowledge the funding received towards my study (the University of Indonesia and Ritsumeikan University) from Professional Human Resource Development (PHRD) IV. I am especially grateful to Bappenas Indonesia and Statistics Indonesia (BPS). I would also like to express my gratitude to Professor Kangkook Lee for his support, encouragement, and suggestions during the research process. 


\section{Appendix}

Appendix 1. Correlation Matrix between Variables

(Poverty Headcount Index, Output Tariff, Input Tariff)

\begin{tabular}{l|rrr} 
& P0 & Output Tariff & Input Tariff \\
\hline P0 & 1.0000 & & \\
Output Tariff & -0.1020 & 1.0000 & \\
Input Tariff & 0.1359 & 0.4286 & 1.0000
\end{tabular}

Appendix 2. Sectoral Share in Employment in Indonesia's Non-Oil/Gas Manufacturing Industry, 2010-2017

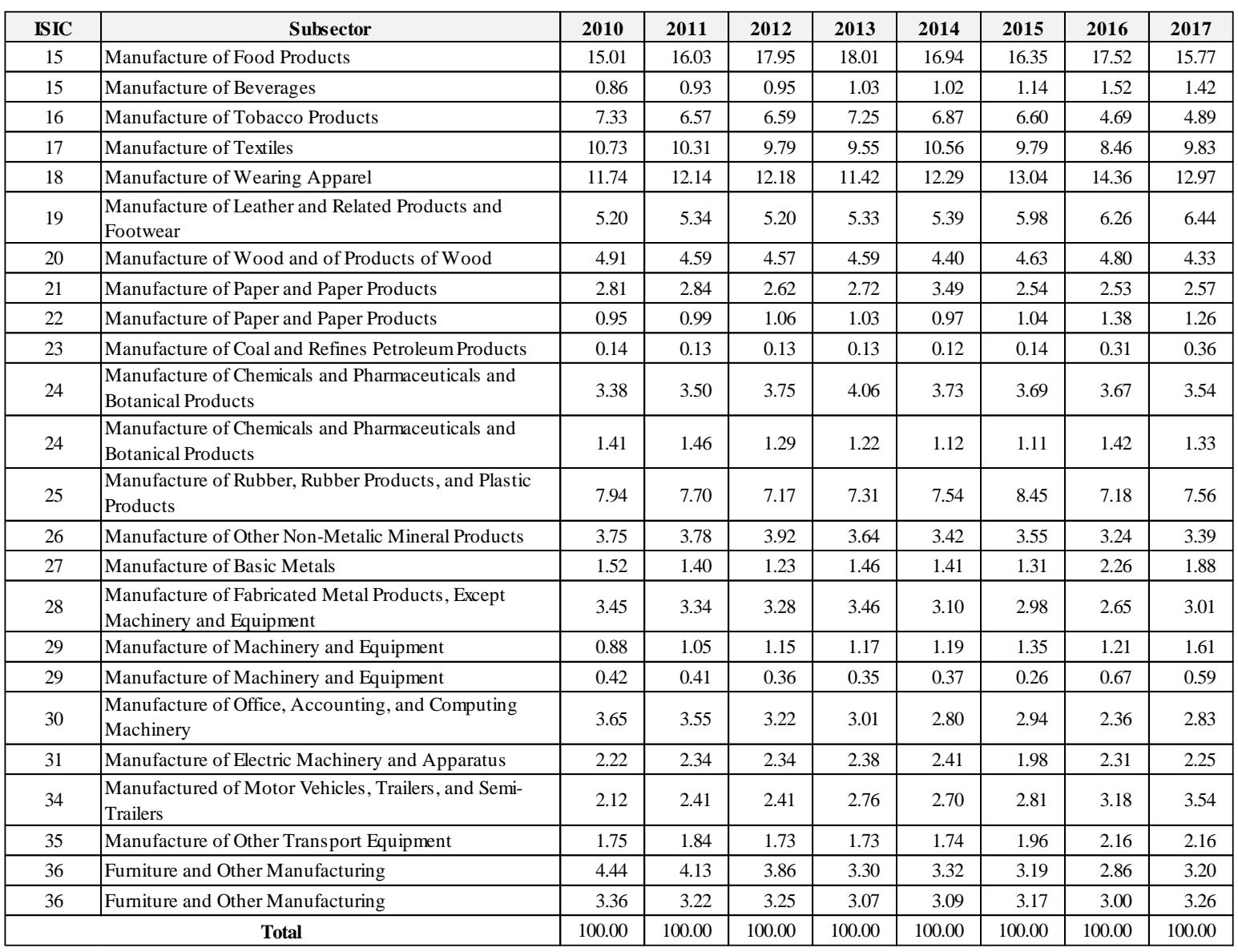

\section{References}

Adha, M. A., Nahar, F. H., \& Azizurrohman, M. (2018). The Impacts of Trade Liberalization on Poverty Reduction in Indonesia. Jurnal Ekonomi Dan Pembangunan, 19(2). https://doi.org/https://doi.org/10.18196/jesp.19.2.5009

Amiti, M., \& Konings, J. (2007). Trade Liberalization, Intermediate Inputs, and Productivity: Evidence from India. American Economic Review, 95(7). https://doi.org/10.1257/aer.97.5.1611

Appleyard, D., Field, A., \& Cobb, S. (2006). International Economics. Boston: McGraw-Hill/Irwin.

Attanasio, O., Goldberg, P., \& Pavcnik, O. (2004). Trade Reform and Wage Inequality in Colombia. Journal of Development Economics, 74(2). https://doi.org/https://doi.org/10.1016/j.jdeveco.2003.07.001

Bhattacharyya, S., \& Resosudarmo, B. (2015). Growth, Growth Accelerations, and the Poor: Lessons from Indonesia.

World

Development

Volume,

66. 
https://doi.org/https://doi.org/10.1016/j.worlddev.2014.08.009

Edmonds, E. V., Pavcnik, N., \& Topalova, P. (2010). Trade Adjustment and Human Capital Investments: Evidence from Indian Tariff Reform. American Economic Journal: Applied Economics, 2(4). https://doi.org/10.1257/app.2.4.42

Goldberg, P., \& Pavcnik, N. (2005). Trade, Wages, and the Political Economy of Trade Protection: Evidence from the Colombian Trade Reforms. Journal of International Economics, 66(1). https://doi.org/https://doi.org/10.1016/j.jinteco.2004.04.005

Hasan, R., Mitra, D., Ranjan, P., \& Ahsan, R. (2012). Trade Liberalization and Unemployment: Theory and Evidence from India. Journal of Development Economics, 97(2). https://doi.org/https://doi.org/10.1016/j.jdeveco.2011.04.002

Kis-Katos, K., \& Sparrow, R. (2015). Labor Markets and Trade Liberalization in Indonesia. Journal of Development Economics, 117. https://doi.org/https://doi.org/10.1016/j.jdeveco.2015.07.005

Kis-Katos, Krisztina, \& Sparrow, R. (2011). Child Labor and Trade Liberalization in Indonesia. Journal of Human Resources, 46(4). https://doi.org/10.3368/jhr.46.4.722

Kovak, B. K. (2013). Regional Effects of Trade Reform: What is the Correct Measure of Liberalization? American Economic Review, 103(5). https://doi.org/10.1257/aer.103.5.1960

McCulloch, N., Winters, L., \& Cirera, X. (2002). Trade Liberalization and Poverty: A Handbook. London: Centre for Economic Policy Research.

Naranpanawa, A., Bandara, J., \& Selvanathan, S. (2011). Trade and Poverty Nexus: A Case Study of Sri Lanka. Journal of Policy Modeling, 33(2). https://doi.org/https://doi.org/10.1016/j.jpolmod.2010.08.008

Nuryitmawan, T. R. (2020). Can Credit Recipient Household Escape from Poverty? The Journal of Indonesia Sustainable Development Planning, 1(3). https://doi.org/https://doi.org/10.46456/jisdep.v1i3.84

Schor, A. (2004). Heterogeneous Productivity Response to Tariff Reduction. Evidence from Brazilian Manufacturing Firms. Journal of Development Economics, 75(2). https://doi.org/https://doi.org/10.1016/j.jdeveco.2004.06.003

Tambunan, T. (2008). Trade Liberalization Effects on The Development of Small and medium-sized Enterprises in Indonesia: A Case Study. Asia-Pacific Development Journal, 15(2).

Topalova, P. (2007). Trade Liberalization, Poverty and Inequality: Evidence from Indian Districts. In Globalization and Poverty. University of Chicago Press.

Winters, L., \& Martuscelli, A. (2014). Trade Liberalization and Poverty: What Have We Learned in a Decade? Annual Review of Resource 6. https://doi.org/https://doi.org/10.1146/annurev-resource-110713-105054

Zuhdiyaty, N., \& Kaluge, D. (2018). Analisis Faktor-Faktor yang Mempengaruhi Kemiskinan di Indonesia Selama Lima Tahun Terakhir. Jurnal Ilmiah Bisnis Dan Ekonomi Asia, 11(2). https://doi.org/https://doi.org/10.32812/jibeka.v11i2.42 